J. Clin. Chem. Clin. Biochem.

Vol. 23, 1985, pp. 505-513

\title{
"Glucose Effect" and Rate Limiting Function of Uroporphyrinogen Synthase on Porphyrin Metabolism in Hepatocyte Culture: Relationship with Human Acute Hepatic Porphyrias
}

\author{
By M. Doss, F. Sixel-Dietrich and F. Verspohl \\ Abteilung für Klinische Biochemie, Fachbereich Humanmedizin der Philipps-Universität Marburg, \\ Bundesrepublik Deutschland
}

(Received January 26/May 8, 1985)

Summary: The effect of glucose on drug-promoted induction of porphyrin synthesis was studied in chick embryo liver cell culture with and without the addition of exogenous $\delta$-aminolaevulinic acid (ALA). Induction of ALA synthase was abolished by haemin or glucose. Less than $10 \%$ of porphobilinogen is converted into protoporphyrin. Protoporphyrin synthesis cannot be enhanced by high ALA concentrations. The conversion of exogenous ALA into porphyrins decreases with increasing concentrations of ALA from 0.1 to $2.0 \mathrm{mmol} / \mathrm{l}$, whereas porphobilinogen accumulates, thus reflecting the rate limiting function of uroporphyrinogen synthase, which is not influenced by glucose. This needle-eye-like function of uroporphyrinogen synthase within the porphyrin biosynthetic chain explains the urinary increase of ALA and porphobilinogen in the acute phase of variegate and coproporphyria, similar to that in acute intermittent porphyria.

The "glucose effect" was also investigated in vivo in humans in 32 courses of hereditary acute hepatic porphyrias (acute intermittent porphyria, variegate porphyria, coproporphyria and porphobilinogen synthase defect porphyria). Patients were treated with high carbohydrate intake $(\sim 500 \mathrm{~g} / 24 \mathrm{~h})$, mainly in the form of glucose infusions. There was a resulting consistent and highly significant decrease of porphyrin biosynthesis metabolites, accompanied by clinical improvement in most of the patients.

"Glucose-Effekt" und limitierende Funktion der Uroporphyrinogen-Synthase auf den Porphyrinstoffivechsel in der Leberzellkultur in Bezug auf die akuten hepatischen Porphyrien des Menschen

Zusammenfassung: Die Wirkung von Glucose auf die Arzneimittel-vermittelte Induktion der Porphyrinsynthese wurde in Hühnerembryo-Leberzellkulturen unter Bedingungen mit endogener und exogener $\delta$ Aminolävulinsäure (ALS) studiert. Die Induktion der ALS-Synthase konnte durch Hämin oder Glucose aufgehoben werden. Weniger als $10 \%$ Porphobilinogen wird in Porphyrine konvertiert. Die Synthese von Protoporphyrin kann unter hohen ALS-Konzentrationen nicht gesteigert werden. Die Umwandlung exogener ALS in Porphyrine fällt mit steigender Konzentration der ALS von 0,1 bis $2,0 \mathrm{mmol} / 1$, während Porphobilinogen akkumuliert: Hierin spiegelt sich die Umsatż-limitierende Funktion der Uroporphyrinogen-Synthase, die nicht durch Glucose beeinflußt wird. Die Nadelöhr-ähnliche Funktion der Uroporphyrinogen-Synthase innerhalb der Porphyrinbiosynthesekette erklärt den Anstieg von ALS und Porphobilinogen im Urin in der akuten Phase der Porphyria variegata und der Koproporphyrie, welcher demjenigen bei akuter intermittierender Porphyrie ähnlich ist.

Der "Glucose-Effekt" in vitro wurde mit dem in vivo beim Menschen verglichen und bei 32 Verläufen hereditärer akuter hepatischer Porphyrien untersucht (akute intermittierende Porphyrie, Porphyria variegata, Koproporphyrie und Porphobilinogen-Synthasedefekt-Porphyrie). Die Patienten wurden mit hoher Kohlenhydrataufnahme $(\sim 500 \mathrm{~g} / 24 \mathrm{~h})$ behandelt, vorwiegend in Form von Glucose-Infusionen. Die biochemische Antwort mit einem Abfall der Porphyrinbiosynthese-Metaboliten war folgerichtig und hochsignifikant, verbunden mit einer klinischen Besserung bei den meisten Patienten. 


\section{Introduction}

The "glucose effect" in experimental allylisoprupylacetamide-induced porphyria, which simulated acute intermittent porphyria, was first demonstrated over 20 years ago by Tschudy's group (1). It could be shown that the porphobilinogenuric effect of allylisopropylacetamide is influenced by diet, and primarily by its carbohydrate and protein content. A subsequent study concluded that the dietary effect on changes in porphyrin precursor excretion in patients with acute intermittent porphyria is related to protein and carbohydrate content rather than total caloric content per se (2). $\delta$-Aminolaevulinic acid (ALA) and porphobilinogen excretion decreased after addition of carbohydrates to the diet. In a third study by Marver, Tschudy and coworkers the effect of carbohydrate feeding on the induction of ALA synthase in experimental acute porphyria in rats was investigated, and it was shown that diet is a regulatory factor in hepatic porphyrin synthesis in porphyria (3, 4). Administration of carbohydrates to rats markedly inhibits the induction of ALA synthase. It was then demonstrated that symptoms and biochemical findings in variegate porphyria were rapidly reversed by intravenous glucose application (5). The observations were explained implying the "glucose effect" on hepatic ALA synthase. However, ALA synthase, the key enzyme of haem biosynthesis, is not the only enzyme subject to the "glucose effect". The induction of two other enzymes, tryptophan oxygenase and tyrosine aminotransferase, is markedly attenuated following the consumption of glucose $(6$, 7).
Porphyria precipitated by fasting (8), porphyrinuria induced by fasting in nonporphyric subjects (9) and "caloripenic porphyria" $(10)$ were next reported and it was suggested that a low-caloric diet or abrupt reduction in carbohydrate and protein intake may provoke symptoms in addition' to elevating urinary ALA, pyrrol and porphyrin excretion $(11,12)$.

The acute hepatic porphyrias are essentially regulatory disorders at the molecular level $(13,14)$ and characterized by inherited enzymatic defects at different stages of the haem biosynthetic sequence (fig. 1). The extreme increase of porphyrin precursor excretion in acute intermittent porphyria, variegate and coproporphyria (13) can only be explained on the basis of the secondarily limiting function of uroporphyrinogen synthase $(15-18)$. Meanwhile the rate limiting function of uroporphyrinogen synthase for the conversion of ALA into protoporphyrin was proven in homogenates (19) and the "glucose effect" was demonstrated in liver cell cultures $(11,20-22)$. In the present study

1. the "glucose effect" on porphyrin synthesis is compared in vitro and in vivo and

2. the intriguing role of uroporphyrinogen synthase as a secondary limiting factor is considered in view of the glucose-mediated repression of counterregulation in acute hepatic porphyrias.

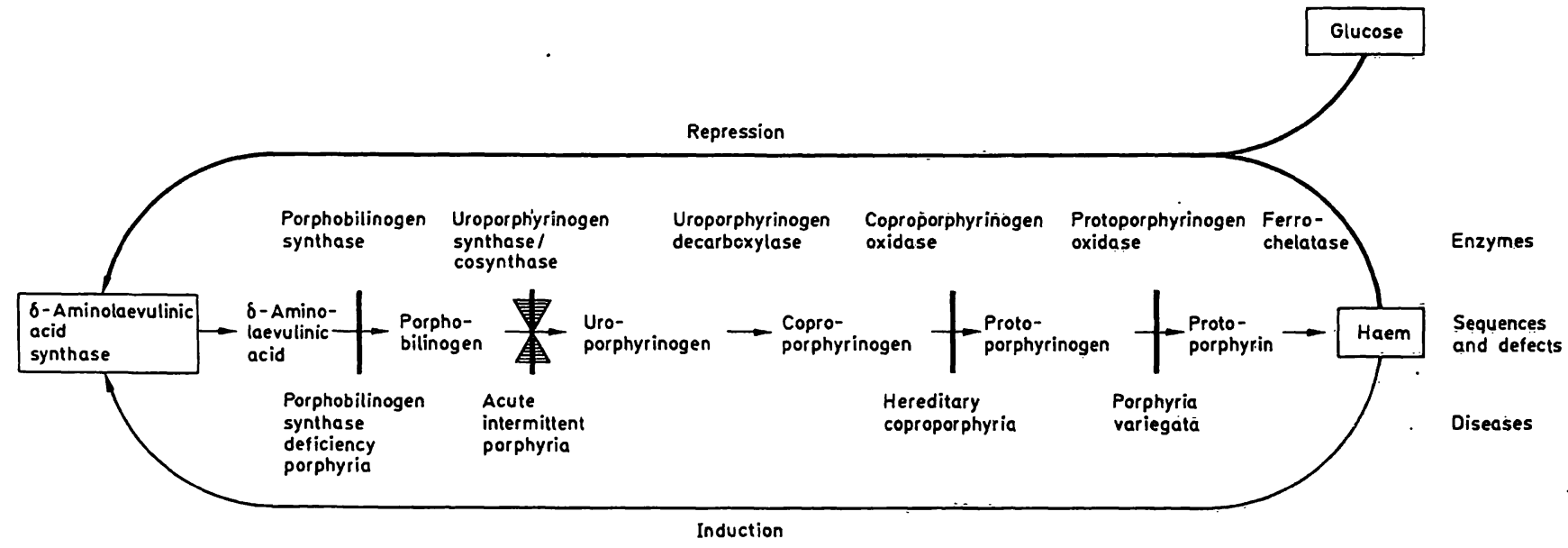

Fig. 1. Enzyme deficiencies and counterregulation in the acute hepatic porphyrias: acute intermittent porphyria, hereditary coproporphyria, porphyria variegata, and porphobilinogen synthase deficiency porphyria. The hereditary enzyme deficiencies of porphobilinogen synthase (EC 4.2.1.24), uroporphyrinogen synthase (EC 4.3.1.8), coproporphyrinogen oxidase (EC 1.3.3.3), and protoporphyrinogen oxidase (EC 1.3.3.4), lead to a destabilization of the regulatory control of haem on the key enzyme of the biosynthetic chain, $\delta$-aminolaevulinic acid synthase (EC 2.3.1.37). Glucose as well as haem represses $\delta$-aminolaevulinic acid synthase. Decrease of "regulatory liver haem" mainly in the acute phase is followed by induction of $\delta$-aminolaevulinic acid synthase. The metabolic conversion of high rates of porphobilinogen into porphyrinogens is generally limited by the secondary controlling step catalyzed by uroporphyrinogen synthase $(\underset{\mathbf{Z}}{\nabla})$. 


\section{Experimental and Clinical Investigation}

\section{Experimental design}

Avian embryo liver cell cultures according to the Granick system (23) were prepared as earlier described (24). Induction of porphyrin synthesis by meprobamate in the chick embryo liver cell culture served as positive control. For the experiment in this study, glucose was replaced in Eagle's basal medium by 10 $\mathrm{mmol} / \mathrm{l}$ sodium pyruvate $(25)$. After one day the medium was changed to fresh medium supplemented with glycine (10 mmol/l), insulin $(200 \mu \mathrm{g} / \mathrm{l})$, glucagon $(40 \mu \mathrm{g} / \mathrm{l})$, and adenosine-3'-, $5^{\prime}$ cyclic monophosphate $(50 \mu \mathrm{mol} / \mathrm{l})$ (Sigma), which was shown to promote the drug-mediated induction (26). Substances listed in table 1 were added, and total protoporphyrin of both cells and medium was measured after $24 \mathrm{~h}$ of further incubation. When the medium was changed, $20 \mu \mathrm{mol} / 1$ laevulinate (Sigma) was added to the medium of those cultures intended for the determination of ALA-S; this laevulinate was added in order to block porphobilinogen synthase, and thereby prevent the further metabolism of newly synthesized ALA. The activity of ALA synthase was determined by the colorimetric method of Sinclair \& Granick (27). In parallel cultures protein was measured by the Lowry method (28).

In a second series of experiments exogenous ALA was added in various concentrations (tab. 2) in order to study the limiting function in uroporphyrinogen synthase and the influence of glucose on this enzyme under high substrate conditions originating from supplemented ALA.

Porphobilinogen was measured after ion exchange and porphyrins after thin-layer chromatography in combination with spectrophotometry and spectrophotofluorometry $(29-31)$.

\section{Patients and methods}

The approach to the differential diagnosis of acute hepatic porphyrias in most of the patients compiled in table 3 was previously described in detail (13). Preliminary diagnoses based on tests for acute hepatic porphyrias (32) were performed to initiate early treatment and omission of porphyrinogenic drugs. ALA and porphobilinogen were isolated by ion exchange chromatography (29), and porphyrins and uroporphyrinogen synthase were analysed as described $(30,31,33)$. Data on accuracy and precision of the analytical methods are presented in foregoing methodical communications $(29,30)$.
Most of the patients were admitted to hospitals for intensive care due to a complex acute porphyria syndrome. Depending on the clinical situation of the patients, glucose treatment took the form of infusions (about $0.3 \mathrm{~g} / \mathrm{kg} \cdot \mathrm{h}$ ) or in combination with a diet rich in carbohydrates so that 450 to $500 \mathrm{~g}$ of carbohydrates per day were received per $70 \mathrm{~kg}$ body weight. Renal elimination of porphyrin precursors and porphyrins was examined daily during the glucose therapy, and molar conversion rates of porphobilinogen to porphyrins were calculated on the basis of these determinations (tab. 4).

\section{Results}

\section{In vitro studies in hepatocytes}

Meprobamate had formerly been proved to be a strong inducer (24). Two characteristic parameters of the inducing process are ALA synthase and protoporphyrin, which is the first and dominant porphyrin accumulating under in vitro conditions and therefore an indicator for the intensity of the induction process. Meprobamate leads to an increase of ALA synthase (12 fold) and protoporphyrin (18 fold) (tab. 1). Haemin or glucose markedly decrease the meprobamate-induced elevation of ALA synthase, porphobilinogen and protoporphyrin. The "glucose effect" is dose-dependent. A glucose concentration of $80 \mathrm{mmol} / \mathrm{l}$ lowers ALA synthase to $33 \%$ and protoporphyrin to $30 \%$ of the inducing level. The corresponding values for haemin $(0.01 \mathrm{mmol} / \mathrm{l})$ are $25 \%$ and $15 \%$, respectively (experiment 3 , tab. 1 ). The porphobilinogen concentration is generally very low (tab. 1). Calculated from these data, only $2.5 \%$ porphobilinogen equivalents are contained in protoporphyrin (experiment 1). Porphobilinogen increases after induction of ALA synthase simultaneously with protoporphyrin (experiment 2). But the conversion of porphobilinogen into porphyrin is only enhanced by $7 \%$.

Tab. 1. Glucose effect in hepatocytes.

Effect of glucose on the meprobamate-induced $\delta$-aminolaevulinic acid (ALA) synthase, pyrrol and porphyrin biosynthesis in avian hepatocytes grown in culture. Results are obtaịned from five parallel experiments: $\bar{x} \pm$ SD (standard deviation).

\begin{tabular}{|c|c|c|c|c|}
\hline Experiment & $\begin{array}{l}\text { Additions to the media } \\
(\mathrm{mmol} / \mathrm{l})\end{array}$ & $\begin{array}{l}\text { ALA synthase } \\
(\mu \mathrm{mol} / \mathrm{h} \cdot \mathrm{g} \text { protein })\end{array}$ & $\begin{array}{l}\text { Porphobilinogen } \\
\text { ( } \mu \mathrm{mol} / \mathrm{g} \text { protein) }\end{array}$ & $\begin{array}{l}\text { Protoporphyrin } \\
\text { (nmol/g protein) }\end{array}$ \\
\hline 1 & None & $30 \pm 10$ & $4 \pm 2$ & $25 \pm$ \\
\hline 2 & Meprobamate (1) & $360 \pm 80$ & $39 \pm 5$ & $710 \pm 60$ \\
\hline 3 & Meprobamate (1) and haemin $(0.01)$ & $90 \pm 30^{*}$ & $26 \pm 4$ & $105 \pm 20^{*}$ \\
\hline 4 & Glucose $(40$ or 80$)$ & $28 \pm 10$ & $5 \pm 2$ & $22 \pm$ \\
\hline 5 & Glucose (40) and meprobamate (1) & $240 \pm 50^{*}$ & $23 \pm 4$ & $450 \pm$ \\
\hline 6 & Glucose (80) and meprobamate (1) & $120 \pm 40^{*}$ & $14 \pm 3$ & $210 \pm 30^{*}$ \\
\hline 7 & Exp. 1 with added ALA (0.1) & & $8 \pm 2$ & $1800 \pm 180$ \\
\hline 8 & Exp. 2 with added ALA (0.1) & & $58 \pm 6$ & $1920 \pm 200$ \\
\hline 9 & Exp. 3 with added ALA (0.1) & & $18 \pm 4$ & $1690 \pm 190$ \\
\hline 10 & Exp. 4 with added ALA (0.1) & & $9 \pm 3$ & $1950 \pm 190$ \\
\hline 11 & Exp. 5 with added ALA (0.1) & & $18 \pm 4$ & $1820 \pm 240$ \\
\hline 12 & Exp. 6 with added ALA (0.1) & & $15 \pm 3$ & $1700 \pm 250$ \\
\hline
\end{tabular}

\footnotetext{
* Significance (Student's t-test) of the difference value marked by * and experiment 2: $\mathrm{p}<0.001$.
} 
Exogenous ALA stimulates porphyrin synthesis. The drug itself and its combination, either with glucose or haemin, did not significantly influence protoporphyrin synthesis from added ALA. The conversion of porphobilinogen into protoporphyrin after meprobamate-promoted induction and ALA supplementation (experiment 8 ) increases up to $13 \%$. Glucose has no influence on the metabolism of porphobilinogen.

The conversion of ALA into porphyrin depends on its concentration up to about $1 \mathrm{mmol} / \mathrm{l}$ (tab. 2). The more ALA is offered to hepatocytes, the less will be transformed into protoporphyrin. As the added concentration of ALA is increased, its utilization decreases to $86 \%$, associated with an accumulation of porphobilinogen. At a concentration of ALA of $2 \mathrm{mmol} / \mathrm{l}$, only $\sim 15 \%$ of porphobilinogen is converted into porphyrin. Thus, in porphyrin synthesis from ALA, protoporphyrin remains the dominant component. :

Tab. 2. Porphobilinogen and porphyrin biosynthesis from exogenous $\delta$-aminolaevulinic acid (ALA) in avian hepatocyte culture $(\bar{x} \pm S D ; n=4)$ without and in the presence of glucose $(40 \mathrm{mmol} / \mathrm{l})$.

\begin{tabular}{|c|c|c|c|c|}
\hline \multirow{2}{*}{$\begin{array}{l}\text { ALA } \\
\text { added }\end{array}$} & \multicolumn{2}{|c|}{$\begin{array}{l}\text { Porphobilinogen } \\
\text { ( } \mu \text { mol/g protein) }\end{array}$} & \multicolumn{2}{|c|}{$\begin{array}{l}\text { Protoporphyrin } \\
\text { (nmol/g protein) }\end{array}$} \\
\hline & $\begin{array}{l}\text { without } \\
\text { glucose }\end{array}$ & $\begin{array}{l}\text { with } \\
\text { glucose }\end{array}$ & & $\begin{array}{l}\text { with } \\
\text { glucose }\end{array}$ \\
\hline & & & & $1700 \pm 180$ \\
\hline 0.5 & $28.4 \pm 3$ & $26.1 \pm 4.3$ & $1950 \pm 200$ & $2100 \pm 170$ \\
\hline 1.0 & $48.3 \pm 6.3^{*}$ & $50.4 \pm 7.0$ & $2200 \pm 190$ & $2050 \pm 250$ \\
\hline 1.5 & $50.6 \pm 7.0$ & $47.8 \pm 9.3$ & $2300 \pm 210$ & $2150 \pm 160$ \\
\hline 2.0 & $54.0 \pm 8.0$ & $57.0 \pm 6.5$ & $2100 \pm 190$ & $2000 \pm 220$ \\
\hline
\end{tabular}

* mean values are significantly different at $\mathrm{p}<0.001$

\section{Clinical-biochemical studies}

High-dose glucose treatment promotes a marked decrease of porphyrin precursor and porphyrin excretion in the three autosomal dominant transmitted acute hepatic porphyrias (acute intermittent porphyria, variegate porphyria and coproporphyria). In 30 patients the decrease in excretion lies between 66 and $91 \%$ of the initial values (tab. 3). In the two patients with the uncommon homozygous porphobilinogen synthase defect porphyria the decrease of metabolite excretion was only $50-70 \%$. The biochemical response to glucose usually occurs after 3 to 5 days, as shown in figure 2 , and is associated with clinical improvement. During the decompensated latency phase, ALA/porphobilinogen ratios and copro-/uroporphyrin ratios are $<1$; with transition to a compensated phase, which is the therapeutic goal, these factors rise $>1$ (fig. 3 ). This increase in connection with a drop of metabolites is judged as a prognostically positive sign.

The change in the hepatic conversion of porphobilinogen into porphyrins, calculated on the basis of the urinary molar excretion ratio of porphobilinogen and porphyrins, is an essential indicator of the acute porphyria disease due to the generally limiting function of uroporphyrinogen synthase in the liver and its specific genetic deficiency in acute intermittent porphyria (33). In the acute phase of acute intermittent porphyria this factor is decreased below the level of controls (tab. 4) due to a synergistic effect of both the limiting function and inherited deficiency of uroporphyrinogen synthase (fig. 1). In variegate and coproporphyria the con-

Tab. 3. Effect of glucose on urinary excretion of $\delta$-aminolaevulinic acid (ALA), porphobilinogen (PBG) and porphyrins (POR) in 32 patients with acute intermittent porphyria, variegate porphyria, hereditary coproporphyria and porphobilinogen synthase defect porphyria.

\begin{tabular}{|c|c|c|c|c|c|c|c|c|c|c|}
\hline \multirow[t]{3}{*}{ Diagnosis and cases } & \multirow{3}{*}{$\begin{array}{l}\text { Glucose } \\
\mathrm{kJ} / 24 \mathrm{~h} \\
\text { (days) }\end{array}$} & \multicolumn{6}{|c|}{ Metabolites $(\mu \mathrm{mol} / 24 \mathrm{~h})$} & \multicolumn{3}{|c|}{ Drop of excretion } \\
\hline & & \multicolumn{3}{|c|}{ before treatment } & \multicolumn{2}{|c|}{ after treatment } & \multirow[b]{2}{*}{ POR } & \multirow{2}{*}{$\begin{array}{l}\% \\
\text { ALA }\end{array}$} & \multirow{2}{*}{$\begin{array}{l}\% \\
\mathrm{PBG}\end{array}$} & \multirow{2}{*}{$\begin{array}{l}\% \\
\text { POR }\end{array}$} \\
\hline & & ALA & PBG & POR & ALA & PBG & & & & \\
\hline $\begin{array}{l}\text { Acute intermittent porphyria } \\
(\mathrm{n}=15)\end{array}$ & 7600 (13) & 846 & 787 & 9 & $219^{*}$ & $265^{*}$ & $3 *$ & 74 & 66 & 67 \\
\hline $\begin{array}{l}\text { Hereditary coproporphyria } \\
(\mathrm{n}=10)\end{array}$ & 7200 & 318 & 405 & 9 & $59 *$ & $36^{*}$ & $2 *$ & 81 & 91 & 78 \\
\hline $\begin{array}{l}\text { Variegate porphyria } \\
(n=5)\end{array}$ & $8400(24)$ & 541 & 429 & 7 & $61^{*}$ & $21^{*}$ & $2^{*}$ & 89 & 95 & 71 \\
\hline $\begin{array}{l}\text { Porphobilinogen synthase } \\
\text { defect porphyria }(n=2)\end{array}$ & $6000 \quad(6)$ & 3520 & 9 & 7 & $1780^{*}$ & $3^{*}$ & $3^{*}$ & 49 & 67 & 57 \\
\hline Upper limit & & 49 & 7.5 & 0.2 & & & & & & \\
\hline
\end{tabular}




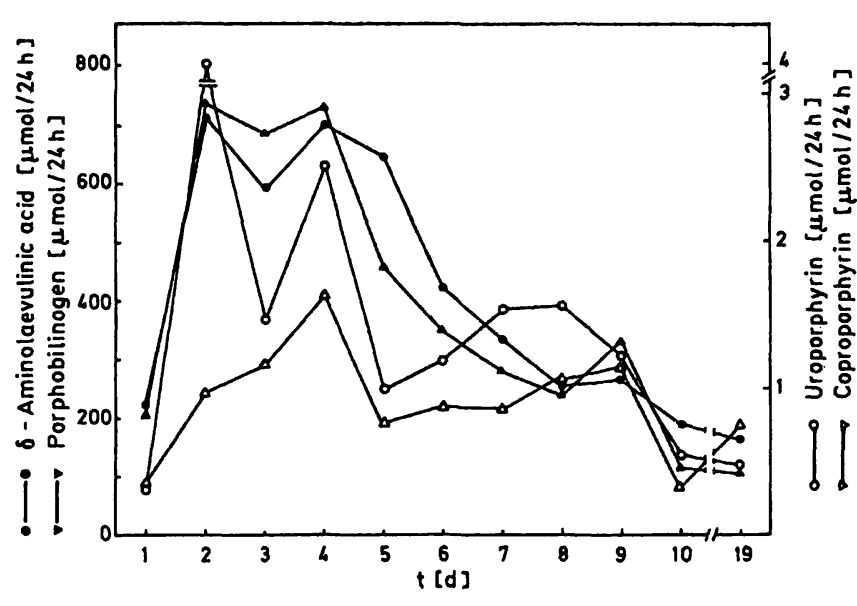

Fig. 2. Biochemical response of haem precursor excretion to glucose treatment ( $400 \mathrm{~g} /$ day) in a 15 year old girl with acute intermittent porphyria which was exacerbated 9 days after mounting doses of valproate up to $600 \mathrm{mg}$ per day.

version factor ranges over 15 , but can drop below 10 in the ascending acute syndrome by excessive induction of ALA synthase. The conversion rate increases under glucose treatment (tab. 4), because of ALA synthase repression and therefore reduced ALA and porphobilinogen formation. The inherited enzyme defect in variegate and coproporphyria (fig. 1) will then become more rate-limiting than the uroporphyrinogen synthase. The activity of uroporphyrinogen synthase is not altered under and after glucose treatment (tab. 4). The activity of this genetic marker in red blood cells is relatively constant within the normal range.

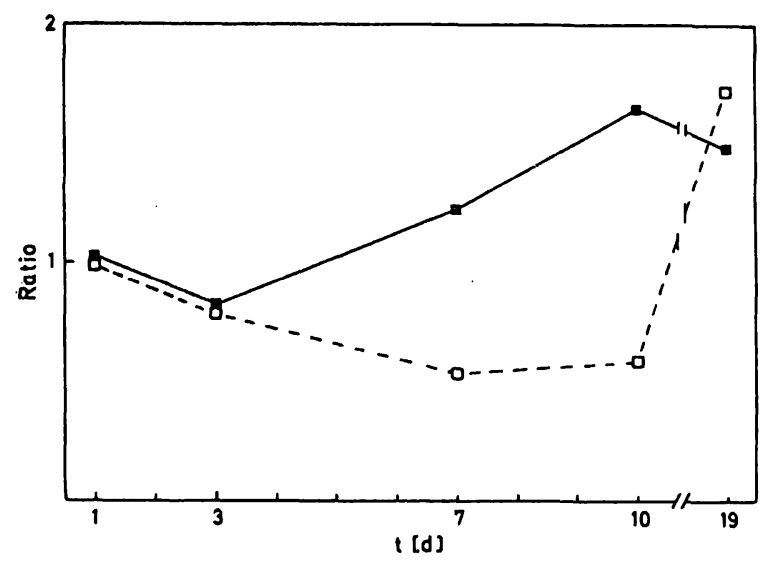

Fig. 3. Course of the $\delta$-aminolaevulinic acid/porphobilinogen (a) and copro-/uroporphyrin ( $\square$ ) ratios in relation to the biochemical response to glucose outlined in figure 2.

In human acute porphyrias the "glucose effect" shows itself

1. in the significant decrease of urinary ALA, porphobilinogen and porphyrin excretion (in variegate and coproporphyria in the fall of faecal porphyrin too),

2. in the increase of the ALA/porphobilinogen and copro-/uroporphyrin ratio in acute intermittent porphyria and

3 . in the increase of the liver conversion rate of porphobilinogen into porphyrin in variegate porphyria and hereditary coproporphyria.

Tab. 4. Effect of glucose on the conversion rates of porphobilinogen to porphyrins related to erythrocyte uroporphyrinogen synthase activity $(\mu \mathrm{mol} / \mathrm{l} \cdot \mathrm{h} ; \overline{\mathrm{x}} \pm \mathrm{SEM})$ in 32 patients with acute intermittent porphyria, hereditary coproporphyria, variegate porphyria and porphobilinogen synthase defect porphyria. Glucose treatment is defined in table 3.

\begin{tabular}{|c|c|c|c|c|}
\hline \multirow{2}{*}{$\begin{array}{l}\text { Diagnosis and cases } \\
\text { Acute intermittent porphyria } \\
(\mathrm{n}=15)\end{array}$} & \multicolumn{2}{|c|}{$\begin{array}{l}\text { Uroporphyrinogen synthase } \\
\text { (\% of controls) } \\
\text { before and after glucose }\end{array}$} & \multicolumn{2}{|c|}{$\begin{array}{l}\text { Conversion rate (\%) } \\
\text { before and after glucose }\end{array}$} \\
\hline & $39 \pm 5(52)^{*}$ & $40 \pm 6(53)^{*}$ & $5.2^{*}$ & $5.5^{*}$ \\
\hline $\begin{array}{l}\text { Hereditary coproporphyria } \\
(\mathrm{n}=10)\end{array}$ & $89 \pm 5(119)$ & $86 \pm 7(115)$ & $24.5^{*}$ & $90.9^{*}$ \\
\hline $\begin{array}{l}\text { Variegate porphyria } \\
(\mathrm{n}=5)\end{array}$ & $77 \pm 2(102)$ & $80 \pm 4(107)$ & 8.9 & $29.6 *$ \\
\hline $\begin{array}{l}\text { Porphobilinogen synthase defect } \\
\text { porphyria }(n=2)\end{array}$ & (108) & (104) & $29.9 *$ & $35.0^{*}$ \\
\hline Controls $(n=12)$ & $75 \pm 2(100)$ & & 9.6 & 10.2 \\
\hline
\end{tabular}

* Significance as compared to controls: $\mathrm{p}<0.001$ (Student's t-test). 


\section{Discussion}

A large number of experimental findings have provided fundamental evidence that the "glucose-effect" is of essential importance in therapy and prophylaxis of acute hepatic porphyrias, and that liver haem biosynthesis is regulated by the influence of nutritional and hormonal factors (34). In acute hepatic porphyrias the excessive induction of ALA synthase as a counterregulatory mechanism is causally associated with the development of the clinical syndrome. Glucose application interferes with ALA synthase induction and represses enzyme synthesis, followed by a decrease in the production of ALA, which possesses neuroinhibitory action (35) and may be held responsible for the neurologic manifestations in hereditary acute porphyrias (36) as well as in acute lead intoxication. ALA appeared more toxic to the neurons than porphobilinogen and other structurally related amino acids tested, possibly causing a critical depletion of energy reserves and cell death (37).

Besides glucose, fructose and glycerol $(38,39)$ also mediate a decrease of urinary porphyrin precursor and porphyrin excretion and an improvement of the clinical course. In our study, however, an increase of erythrocyte uroporphyrinogen synthase activity under carbohydrate treatment (39) was not detected. The metabolic response was consistent in the 32 courses studied (tab. 3) and resulted in a clinical improvement in 28 cases. These observations agree with those of Stein \& Tschudy (40) who reported a favorable clinical response to glucose in acute intermittent porphyria. Otherwise the response of different patients to a high carbohydrate diet varied from "spectacular clinical improvement" to little effect (41). There was no explanation for the heterogeneity of responsiveness, but it has been assumed that abnormalities in carbohydrate metabolism in acute intermittent porphyria lead to a decreased glucose tolerance. Probably gluconeogenesis is stimulated in acute porphyria syndrome, associated with a decrease in the insulin-glucagon-ratio. Studies in liver cells support this assumption, as the allylisopropylacetamide-induced porphyrin synthesis depends on a low insulin/glucagon ratio (42), but is independent under special conditions (20). Individual variations in the influence of nutritional and hormonal factors, including the link between sex hormones and porphyrin metabolism (34) cannot explain the variations in responsiveness to glucose. An evaluation of the therapeutic studies (tab. 3) has clearly shown that clinical response and improvement are mainly dependent on the clinical condition of the patient when glucose treatment is initiated. An early start of glucose application is of utmost importance. At an advanced point of the neurologic syndrome, when a transition from a functional to a structural disturbance has already proceeded, most likely under the neurotoxic effect of ALA, neither glucose nor haematin (43) can improve the clinical condition immediately.

\section{In vitro studies on hepatocyte culture}

Synthesis of ALA synthase is subject to feedback regulation by haem (23). In mammalian liver, the inhibition by haem appeared to occur mainly at the posttranscriptional stage (44), although earlier data includes the possibility that haem also interferes in the level of transcription (3). Dose response relationships have shown that increasing amounts of glucose progressively impair the induction of hepatic ALA synthase in vivo (38). A similar effect was found in avian hepatocytes (tab. 1). Other investigators also demonstrated that the increase of ALA synthase in vitro by fasting or phenobarbital-mediated induction can be prevented or diminished by glucose $(20,22)$. Fructose, glycerol and lactate mimicked the inhibitory glucose effect on ALA synthase which is reversed by 2-deoxyglucose (20). The conversion of ALA into porphyrin is reflected by the amount of protoporphyrin synthesized, which represents $70-95 \%$ of the porphyrin that accumulates under in vitro conditions $(19,24)$, also from added ALA. It has been concluded that the accumulation of protoporphyrin is due to the limiting activity of ferrochelatase $(16,19,45)$. The normal liver contains protoporphyrin as the dominant component (> $70 \%$ ), thus reflecting its controlled utilization.

In order to increase the conversion of ALA into porphyrin increasing amounts of ALA were offered to hepatocyte culture (tab. 2). But the synthesis of protoporphyrin could not be enhanced. Porphobilinogen accumulated and was not metabolized to porphyrinogen, in analogy with the studies in homogenates of chick and rat liver (19). Glucose did not stimulate the conversion of porphobilinogen from added ALA into porphyrin (tab. 4), suggesting that uroporphyrinogen synthase is the rate limiting enzyme in the haem biosynthetic chain in hepatic haem synthesis under conditions of high substrate availability, i. e. excess of ALA either after induction of ALA synthase or after ALA supplementation. In the liver, the $V_{\max }$ of uroporphyrinogen synthase is probably very close to the $V_{\max }$ of ALA synthase (18). Both enzymes implicate regulatory functions, but only ALA synthase can be controlled by glucose. 
Crucial role of hepatic uroporphyrinogen synthase in human

The simultaneously elevated excretion of ALA and porphobilinogen in acute intermittent porphyria, coproporphyria and variegate porphyria in the acute crisis is the product of a counterregulatory enhancement after induction of liver ALA synthase. Porphyrin excretion is also increased in all three conditions, although only acute intermittent porphyria shows a hereditary uroporphyrinogen synthase defect (13). These results lead to the theory of biochemical transition between these three acute porphyrias (16). The expression of the clinical symptoms seems to depend on the unlimited formation (ALA synthase induction) and limited metabolism of porphyrin precursors. According to the results presented here, glucose has an exclusive influence on the reduction of ALA synthesis but not on its metabolism to porphobilinogen and porphyrins.

The activity of uroporphyrinogen synthase is very low. Its $K_{\mathrm{m}}$ is approximately $10^{-6} \mathrm{~mol} / \mathrm{l}$ and probably higher than the normal porphobilinogen concentration in the liver, which might be less than $10^{-6}$ $\mathrm{mol} / \mathrm{l}(46)$. When the porphobilinogen concentration increases after induction of ALA synthase or after ALA loading, e.g. to $10^{-4} \mathrm{~mol} / \mathrm{l}$, the activity of uroporphyrinogen synthase is not sufficient for an efficient conversion of porphobilinogen into porphyrin. The step catalysed by uroporphyrinogen synthase has an apparent "needle-eye-like function". It has also been described as a "physiological bottleneck" (19). This rate limitation becomes pathologically severe in conditions of increased substrate availability, as shown by studies in acute intermittent porphyria patients and after oral ALA loading, both in controls and in latent acute intermittent porphyria (31). Under ALA loading in controls $(12 \mathrm{mg} / \mathrm{kg})$ the conversion rate drops from 9 to $3 \%$, and in latent acute intermittent porphyria from 8 to $4 \%$ demonstrating the limited utilization of porphobilinogen by uroporphyrinogen synthase under substrate oversaturation. The "physiological bottleneck" explains the similar increase of both porphyrin precursors in the three acute porphyrias and therefore the similarity of abdominal and nervous symptoms which are correlated to the increase of ALA and porphobilinogen (36). Although glucose has no direct influence on uroporphyrinogen synthase, the glucose-mediated repression of ALA synthase indirectly eases the substrate pressure on uroporphyrinogen synthase and harmonizes porphyrin synthesis. As uroporphyrinogen synthase is not genetically disturbed in variegate and coproporphyria, diminution of ALA and porphobilinogen excretion will occur even more dramatically and faster than in acute intermittent porphyria with hereditary uroporphyrinogen synthase defect (tab. 4).

Thoughts on mechanisms underlying the glucose effect

The following is an attempt to elaborate a working hypothesis for the effector mechanism of glucose on hepatic porphyrias (fig. 4), a phenomenon which is also mediated by fructose and glycerol. The question of the "glucose effect" concerns the carbohydrate repression of enzyme induction, RNA synthesis, and glucocorticoid activity as well as the role of cAMP and cGMP $(20,47-49)$. The "glucose effect" seems to be promoted by intra- and extrahepatic factors in humans. Glucose as well as haem inhibit the drugmediated induction of hepatic ALA synthase and the intracellular translocation of cytosolic to mitochondrial ALA synthase (fig. 4). Both the synthesis and the intracellular translocation of ALA synthase may be regulated by the variation of a 'regulatory haem pool' in a physiological range in the liver cell (44) which is destabilized by hereditary enzymatic defects (fig. 1) and thereby sensitized to drug action (13). Depletion of this 'regulatory hepatic haem pool' in pharmacogenetic diseases like acute hepatic porphyrias results in a high induction of ALA synthase (14), which is a counterregulatory event.

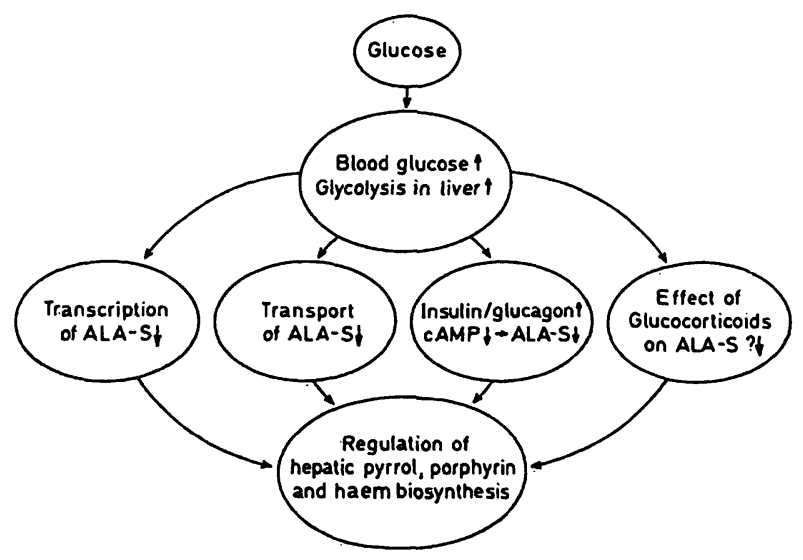

Fig. 4. The "glucose effect": a hypothetical synopsis shows the synergism of various hepatic and extrahepatic effector mechanisms of glucose on the key enzyme of overall porphyrin and haem biosynthesis, ALA synthase (ALAS), in the liver. 
It can be prevented, controlled and suppressed by glucose. Probably independently of these mechanisms, hormonal factors also modulate porphyrin synthesis in liver: ALA synthase induction is diminished by an increase of the insulin-glucagon-ratio with consequent lowering of CAMP (26), which may play a "permissive" role for the induction of ALA synthase, similar to the effect of glucocorticoids. With regard to the influence of extrahepatic factors on hepatic ALA synthase, findings and evidence are controversial and discussed elsewhere $(20,34)$.

\section{Conclusion}

Three points arising from these results should be stressed:

1. The "glucose effect" on porphyrin synthesis is reproducible under experimental conditions and provides ai rational dimension for the high carbohydrate treatment of acute hepatic porphyrias.

\section{References}

1. Rose, J. A., Hellman, E. S. \& Tschudy, D. P. (1961) Metabolism 10, 513-421.

2. Welland, F. H., Hellman, E. S., Gaddis, E. M., Collins, A., Hunter, G. W. \& Tschudy, D. P. (1964) Metabolism 13, 232-250.

3. Marver, H.S., Collins, A., Tschudy, D.P. \& Rechcigl, Jr., M. (1966) J. Biol. Chem. 241, 4323-4329.

4. Tschudy, D. P., Welland, F. H., Collins, A. \& Hunter, G. (1964) Metabolism 13, 396-406.

5. Perlroth, M. G., Tschudy, D. P., Ratner, A., Spaur, W. \& Redeker, A. (1968) Metabolism 17, 571-581.

6. Bonkowsky, H. L., Collins, A., Doherty, J. M. \& Tschudy, D. P. (1973) Biochim. Biophys. Acta 320, 561- 576.

7. Wetterberg, L., Geller, E. \& Yuwiler, A. (1970) Biochem. Pharmac. 19, 2833-2838.

8. Knudsen, K. B., Sparberg, M. \& Lecogq, F. (1967) Nèw Engl. J. Med. 277, 350-351.

9. Koskelo, P. \& Pelkonen, R. (1968) New Engl. J. Med. 278, 856-856.

10. Felsher, B. F. (1967) New Engl. J. Med. 277, 883 - 884.

11. Doss, M. \& Verspohl, F. (1981) Klin. Wochenschr. 59, 727-735.

12. Felsher, B. F. \& Redeker, A. G. (1967) Medicine 46, 217-223.

13. Doss, M. O. (1982) In: Progress in Liver Diseases, Vol. VII (Popper, H. \& Schaffner, F., eds.) pp. 573-597, Grune \& Stratton, New York.

14. Matteis, F. de (1978) In: Heme and Hemoproteins (Matteis, F. de \& Aldridge, W. N., eds.) pp. 129-155, Springer, Berlin.

15. Brodie, M. J., Moore, M. R. \& Goldberg, A. (1977) Lancet II, 699-701.

16. Doss, M. (1978) Int. J. Biochem. 9, 911-916.

17. Elder, G. H. (1976) Essays Med. Biochem. 2, 75-114.

18. Meyer, U. A. (1978) In: Diagnosis and Therapy of Porphyrias and Lead Intoxication (Doss, M., ed.) pp. 3-7, Springer, Berlin.
2. The limiting function of uroporphyrinogen synthase observed in humans under oral ALA loading as well as in acute porphyrias can be simulated experimentally in hepatocytes in vitro after induction of ALA synthase and variation of the amount of exogenous ALA. The relationship between porphobilinogen and protoporphyrin concentration is reciprocal and not influenced by glucose.

3. The "glucose effect" in acute clinical porphyrias can be considered as the therapy of choice. Its efficiency is in no way inferior to that of haematin. Glucose/fructose may and should be administered even as prophylaxis in cases of clinical suspicion.

\section{Acknowledgement}

The experimental work was supported by the Deutsche Forschungsgemeinschaft (Grant DO 134). The authors thañk Ms. Angelika Nitz for typing the manuscript, and Ms. Heidrun Baumann and Ms. Martina Bernshausen for skillful laboratory assistance.
19. Healey, J. F., Bonkowsky, H. L., Sinclair, P. R. \& Sinclair J. F. (1981) Biochem. J. 198, 596-604.

20. Giger, U. \& Meyer, U. A. (1981) J. Biol. Chem. 256, 11182-11190.

21. Hickman, R., Saunders, S. J., Dowdle, E. \& Eales, L. (1968) Biochim. Biophys. Acta 161, 197-204.

22. Schoenfeld, N., Greenblat, Y., Epstein, O., Lahav, M., Beigel, Y. \& Atsmon, A. (1982) FEBS Lett. 138, 277-279.

23. Granick, S. (1966) J. Biol. Chem. 241, 1358-1375.

24. Doss, M. (1968) FEBS Lett. 2, 127- -129.

25. Ludwig, H. \& Rott, R. (1975) J. Virol. 16, 217-221.

26. Srivastava, G., May, B. K. \& Elliott, W. H. (1979) Biochem. Biophys. Res. Comm. 90, 42-49.

27. Sinclair, P. \& Granick, S. (1977) Analyt. Biochem. 79, 380-393.

28. Lowry, C. H., Rosenbrough, N. I., Farr, A. L. \& Randall, R. J. (1971) J. Biol. Chem. 193, 265-275.

29. Doss, M. \& Schmidt, A. (1971) Z. Klin. Chem. Klin. Biochem. 9, 99-102.

30. Doss, M. (1974) In: Clinical Biochemistry, Principles and Methods, Vol. 2 (Curtius, H. Ch. \& Roth; M., eds.) pp. 1323-1371, de Gruyter, Berlin.

31. Doss, M. (1973) Enzyme 16, 343-353.

32. Doss, M. (1971) Lancet $I I, 983-984$.

33. Meyer, U. A., Strand, L. J., Doss, M., Rees, A. C. \& Marver, H. S. (1972) New Engl. J. Med. 286, 1277-1282.

34. Tschudy, D. P. (1978) In: Heme and Hemoproteins (Matteis, F. de \& Aldridge, W. N., eds.) pp. 255-271, Springer, Berlin.

35. Brennan, M. J. W., Cantrill, R. C. \& Kramer, S. (1980) Int. J. Biochem. 12, 833-835.

36. Bonkowsky, H. L., Schady, W. (1982) Semin. Liver Dis. 2, $108-124$.

37. Russell, V. A., Lamm, M. C. L. \& Taljaard, J. J. F. (1982) Neurochem. Res. 7, 1009-1022.

38. Bonkowsky, H. L., Magnussen, C. R., Collins, A. R., Doherty, J. M., Hess, R. A. \& Tschudy, D. P. (1976) Metabolism $25,405-414$. 
39. Brodie. M. J.. Moore. M. R.. Thompson, G. G. \& Goldberg. A. (1977) Clin. Sci. Mol. Med. 53. 365-371.

40. Stcin. J. A. \& Tschudy. E. P. (1977) Medicine 49, 1-16.

41. Tschudy, D. P.. Valsamis, M. \& Magnussen, C. R. (1975) Ann. Int. Med. 83, 851-864.

42. Fischer. P. W. F., Stephans, J. K. \& Marks, G. S. (1978) Molec. Pharmacol. 14, 717-72.1.

43. Pierach. C. A., Bossemaier, I.. Cardinal, R., Weimer, M. \& Watson. C. J. (1980) Klin. Wochenschr. 58, 829-832.

44. Kikuchi. G.. Hayashi. N. (1981) Mol. Cell. Biochem. 37, $27-41$.
45. Wagner, G. S., Dinamarca, M. L., Tephly, T. R. (1976) In: Porphyrins in Human Diseases (Doss, M., ed.) pp. 111-122, Karger, Basel.

46. Strand, L. J., Felsher, B. F., Redeker, A. G. \& Marver, H. S. (1970) Proc. Nath. Acad. Sci. USA 67, 1315-1320.

47. Goldberg. M. L. (1974) Life Sci. 17, 1747-1754.

48. Kim, H. J. \& Kikuchi, G. (1974) Arch. Biochem. Biophys. 164, 293-304.

49. Marver, H. S., Collins, A. \& Tschudy, D. P. (1966) Biochem. J. $99,31 c-33 c$.

Pror. Dr. M. Doss

Abt. f. Klinische Biochemie

FB Humanmedizin d. Universität

Deutschhausstraße 17 1/2

D-3500 Marburg (Lahn) 
